\title{
Comprehensive Evaluation of Road Network Smooth Characteristic based on Different Service Objects
}

\section{WANG}

School of Economics and Management, Chang'an University, Xi'an 710064, China

W. B. YANG

Department of Specialized Course, Architecture Zabor University of Shaanxi province, Xi'an 710068, China

\begin{abstract}
According to the development philosophy of the transportation industry that "easy traveling of people and smooth flow of goods", this paper states the smooth characteristic and the meaning of service objects of highway. Take Shandong Province as example, the technical and economic evaluation system of highway network smooth characteristic is established based on the transportation demands of service objects-passengers and goods owners. Through comprehensive evaluation analysis, some suggestions for promoting the smooth characteristic of highway network and coordinated economic development in Shandong Province are put forward. Research results can provide beneficial reference for better overall efficiency of the system performance optimization of the road network.

KEYWORD: Transport demand; Road network; Smooth characteristic; Service object; Comprehensive evaluation
\end{abstract}

\section{INTRODUCTION}

The idea that "easy traveling of people and smooth flow of goods" is the basic characteristics to judge whether the transportation industry of the country is able to adapt to the needs of the national economy and social development (Qin 2005 \& Amy 1998). With the development of national economy and society, the country continues to increase investment in infrastructure, especially in the field of road infrastructure, the purpose of which is to better serve transportation (Wu et al. 2007 \& Zhang et al. 2002). However, the phenomenon of "disconnect" between road construction and transportation is relatively common in practice. Meanwhile, the road traffic flow and passenger flow is little although these roads were built long, which didn't play its proper economic and social benefits. This made the superiority of the road network system function and the advantages to the development of transport not evident. Therefore, it is necessary to conduct the comprehensive evaluation of road network smooth characteristic based on different service objects

\section{MEANING OF THE SMOOTH CHARACTERISTIC OF ROAD}

The smooth traffic of road now is more regarded as the phenomenon that the traffic demand within a certain time (within a certain time through a number of road vehicles) less than the traffic capacity of a road (the road within a certain time can through the maximum total vehicle) under normal conditions. In this paper, smooth traffic is a combination concept, of which "accessibility" is static and "liquidity" is dynamic. There are two layers of meaning: the first is "accessibility" in the traditional sense, which can be understood as the realization of the passenger and goods displacement have enough path, and make the service object can flow and realize the displacement between origin and destination, not stagnation; the second is "liquidity", which means that the vehicle running status between origin and destination meet the needs of the demand subject, which is the quality problem of the "accessibility", namely the extent problem of the "accessibility".

\section{MEANINGS OF ROAD SERVICE OBJECT}

The so-called road service object is the object entity which accomplishes displacement by running on the road, which can be divided into the direct service objects of road and the most basic service object of road.

\subsection{Direct Service Objects of Road}

The purpose of building roads is to make sure cars complete transportation service on the road conveniently, safely and comfortably. Therefore, as 
the most direct benefits, various passable vehicles is the direct service object of road.

\subsection{Most Basic Service Object of Road}

The most basic service objects of road are passenger and shipper, which use the road to realize passenger and goods displacement to meet the demand of transportation. Road and vehicle are traffic infrastructure in the service of transport activities, and both structure road traffic system, thus serve passengers and goods displacement. Traffic infrastructure is just the means used to serve passenger and goods displacement, and successfully complete the displacement is the real purpose. That is to say, road is built for the exchange of passenger and goods. In order to evaluate the smooth characteristic of road more intuitively, the demand analysis of passenger and shipper were selected to research the comprehensive evaluation in this paper.

\section{SMOOTH CHARACTERISTIC EVALUATION SYSTEM OF ROAD NETWORK AND ITS COMPREHENSIVE EVALUATION}

\subsection{Establishment of Smooth Characteristic Evaluation System of Road Network Based on Transportation Demands (Take Shandong Province as Example)}

The realization degree of transportation demands of passengers is affected directly by the traffic condition of the highway network. What passengers want to get about transportation service is "convenient", which reflects not only the accessibility problem but also the smooth function of highway network. has two types-time sensitive type and price sensitive type and the different transportation demands have different requirements to the transportation supply quality, resulting in the different choice of transport corridor. Based on that, this paper selects evaluation indexes according to the classification of passenger transport, and then analyzes the evaluation results integrally.

\subsubsection{Smooth characteristic index of highway network influencing the demand of passengers' transportation}

With the continuous economic development in Shandong province, passengers have higher demands of travelling conveniently and fast. In order to meet the transportation requirements, this paper focuses on the proportion of grade II and higher rank highway, technical grade of artery road network and road network average travelling speed as the evaluation indexes of highway network smooth characteristic.

(1) Grade II and higher rank highway of artery

The reason for choosing this evaluation index is that passengers feel more comfortable during travelling out than the highway with lower ranks. According to the <Research on index of Chinese highway modernization> made by Planning and Design Institute of Department of Transportation of China (see Table 1), the proportion of grade II and higher rank highway in Shandong province reaches $94 \%$, indicating its arterial highway modernization is very high.

Table 1 Evaluation standard of highway modernization index

\begin{tabular}{|c|c|c|c|}
\hline Evaluation Index & National Standard & \multicolumn{2}{|c|}{ Western Region Standard } \\
\hline $\begin{array}{c}\text { Proportion of Grade II and Higher Rank } \\
\text { Arterial Highway (\%) }\end{array}$ & 51 & 85 & 36 \\
\hline
\end{tabular}

(2) Technical grade of artery road network

Technical grade of artery road network can comprehensively reflect the overall situation of road network technical which can directly reflect the highway traffic conditions. Therefore, it is an important index for investigation of highway network structure in Shandong province. It can be calculate by Eq.1.

$$
G=\left(\sum L_{i} G_{i}\right) / \sum L_{i}=
$$

$1 \times 6353.2+2 \times 23836.1+3 \times 24249.4+4 \times 149246.8+5 \times 4517.7$

$$
212236.3
$$

Where: $\mathrm{G}$ means highway network grade level (more than 0 and less than 5); Li means highway mileage of each section intra-region (unit: kilometer); Gi means the technical grade for each section intra-region, which is set $0,1,2,3,4,5$ corresponding for freeway, grade I highway, grade II highway, gradeIIIhighway and grade IV highway respectively. Meanwhile, Artery highway network technical grades are defined as follows: when $G$ is less than 2, it stands for "good"; when G is more than 2 and less than 3, it stands for "general"; when $\mathrm{G}$ is more than 3 and less than 4, it stands for "poor"; when $\mathrm{G}$ is more than 3 and less than 4 , it stands for "very poor". According to this standard, highway network technical grade of Shandong province is near Grade IV, which is low to some extent.

(3) Artery road network average travelling speed

Artery road network average travelling speed is decided by the comprehensive effect of artery road in highway traffic system, vehicle system and management system. It reflects the system property of road network and is considered as an important 
index of highway traffic service quality. It can be calculate by Eq. 2 .

$$
V=\frac{\sum_{i}\left(V_{i} L_{i} q_{i}\right)}{\sum_{i}\left(L_{i} q_{i}\right)}=73.02 \mathrm{~km} / \mathrm{h}
$$

Where: $V$ means artery road network average travelling speed (unit: $\mathrm{km} / \mathrm{h}$ ); $V i$ means average travelling speed on the section $i$ of road network (unit: $\mathrm{km} / \mathrm{h}$ ); $L i$ means mileages of on the section $i$ of road network (unit: $\mathrm{km}$ ); $q_{i}$ means traffic volume on the section $i$ of road network (unit: veh/d). Meanwhile, artery road network average travelling speed are defined as follows: when $V$ is more than 85 , it stands for "good"; when $V$ is more than 75 and less than 85, it stands for "general"; when $V$ is more than 55 and less than 75, it stands for "poor"; when $V$ is less than 55, it stands for "very poor". According to this standard, artery road network average travelling speed of Shandong province is low to some extent.

\subsubsection{Highway network flow index of impact on transport demand}

(1) The emphasis to maximize the realization of transport demand is to consider the patency of internal road network system for time-sensitive goods. This transport demand generally requires highly smooth traffic. Therefore, the indexes such as artery network saturation and network crowded rate are selected.

\section{(1)Artery network saturation}

Artery network saturation is the weight ratio of actual traffic load and the maximum permissible traffic load and reflects the network flow as well as the overall balance and reserve situation of the network capacity. The index characterizes the smooth performance of the road network as a whole, is one of the important technical indicators of the network adaptability. It is calculated according to Eq. 3.

$$
P=\sum_{j=1}^{m} Q_{j} S_{j} / \sum_{j=1}^{m} C_{j} S_{j}=0.537
$$

Where: ${ }^{S_{j}}$ : Length of $\mathrm{j}$ section or average travel; $Q_{j}$ : Flow of j section.

This paper argues that the network saturation is more reasonable at 0.7 to 0.8 to avoid excessive waste of highway capacity and the traffic maintains the basic flow. Finalize the evaluation criteria as follows: When $\mathrm{P}<0.5$, good; When $0.5 \leq \mathrm{P}<0.7$, generally; when $0.7 \leq \mathrm{P}<1.0$, poor; When $\mathrm{P} \geq 1.0$, very poor. The artery network saturation is 0.537 in Shandong province and it is at a general level from the calculation results.

\subsection{Analysis of comprehensive and results of Shandong province highway network flow evaluation}

\subsubsection{Comprehensive analysis and evaluation of Shandong province highway network unblocked}

The calculation result of Shandong province highway network unblocked state of each index can be seen in Table 2.

\begin{tabular}{|c|c|c|c|}
\hline Index & $\begin{array}{l}\text { The calculation } \\
\text { results }\end{array}$ & The evaluation benchmark & $\begin{array}{l}\text { The evaluation } \\
\text { results }\end{array}$ \\
\hline $\begin{array}{l}\text { Trunk line road two road over } \\
\text { the proportion }\end{array}$ & $94 \%$ & $\begin{array}{l}\text { When the index value } \geq 85 \% \text {, smooth in good } \\
\text { condition; when } 51 \% \leq \text { index value }<85 \% \text {, the general; } \\
\text { when the index value }<36 \% \text {,Very poor. }\end{array}$ & $\begin{array}{l}\text { Higher levels (4 } \\
\text { points) }\end{array}$ \\
\hline $\begin{array}{l}\text { Trunk line network average } \\
\text { technology level }\end{array}$ & 3.52 & $\begin{array}{l}\text { When } \mathrm{G}<2 \text {,fine; when } 2 \leq \mathrm{G} \leq 3 \text {, the general; when } 3< \\
\mathrm{G} \leq 4 \text {, the poorer; when } \mathrm{G}>4 \text {, Very poor. }\end{array}$ & $\begin{array}{l}\text { Low grade }(2 \\
\text { points) }\end{array}$ \\
\hline $\begin{array}{l}\text { Trunk line network average } \\
\text { speed }\end{array}$ & 73.02 & $\begin{array}{l}\text { When } \mathrm{V} \geq 85 \text {, Trunk line network average speed } \\
\text { reflects road network unblocked state is the fine; when } \\
75 \leq \mathrm{V}<85 \text {, the general; when } 55 \leq \mathrm{V}<75 \text {, the poorer; } \\
\text { when } \mathrm{V}<55 \text {, Very poor. }\end{array}$ & $\begin{array}{l}\text { the poorer }(2 \\
\text { points) }\end{array}$ \\
\hline $\begin{array}{l}\text { Trunk line the saturation of road } \\
\text { network }\end{array}$ & 0.537 & $\begin{array}{l}\text { When } \mathrm{P}<0.5 \text {, the fine; when } 0.5 \leq \mathrm{P}<0.7 \text {, the general; } \\
\text { when } 0.7 \leq \mathrm{P}<1.0 \text {, the poorer; when } \mathrm{P} \geq 1.0 \text {, Very poor. }\end{array}$ & $\begin{array}{l}\text { The level of } \\
\text { general ( } 3 \text { pionts) }\end{array}$ \\
\hline Road network congestion rate & $13.4 \%$ & $\begin{array}{l}\text { When Ps }<10 \% \text {, road network unblocked state } \\
\text { indicators reflect the good ; when } 10 \% \leq \mathrm{PS}<15 \% \text {, the } \\
\text { general; when } 15 \% \leq \mathrm{PS}<20 \% \text {, the poorer; when } \\
\mathrm{PS} \geq 20 \% \text {,Very poor. }\end{array}$ & $\begin{array}{l}\text { The level of } \\
\text { general ( } 3 \text { pionts) }\end{array}$ \\
\hline $\begin{array}{lcr}\text { Road } & \text { network } & \text { internal } \\
\text { development equilibrium degree }\end{array}$ & 3.95 & $\begin{array}{l}\text { When } \mathrm{H} \geq 5 \text {, the fine; when } 3 \leq \mathrm{H}<5 \text {, the general; when } \\
1 \leq \mathrm{H}<3 \mathrm{H}<1 \text {, Very poor. }\end{array}$ & $\begin{array}{l}\text { The level of } \\
\text { general ( } 3 \text { pionts) }\end{array}$ \\
\hline Summary & \multicolumn{3}{|c|}{ Shandong province highway network flow level remains to be further improved } \\
\hline
\end{tabular}

Table 2 Highway network flow comprehensive evaluation system of Shandong province

Through the analysis and comparison of comprehensive, The highway average technology level is lower in Shandong province and it is 3.52; The proportion of secondary road is $94 \%$ of main road, Shandong provincial trunk highway modernization level is higher than the standards of national highway modernization which level is $85 \%$, concerning the road congestion rate, two grade 
highway mileage too crowded, The saturation of dry line is 0.537 which in the general level in Shandong Province. Shandong province highway network internal development equilibrium degree is 3.95, which in the general level.

The respective weight of these indicators are assigned to equivalence, put each index all as equally important, According to the good, general, poor and very poor four grades on the basis of evaluation results ( 4 points, 3 points, 2 points, 1 points, only three grade by 4 points, 2.5 points, 1 points to comment), Calculate the smooth degree of Shandong province highway network is:

\section{$(4+2+2+3+3+3) / 6 \approx 2.83$}

By summarizing the influence and reflection about the various indicators of Shandong province highway network flow state, we can draw the conclusion that the smooth level of Shandong province highway network needs to be improved further space and potential at this stage.

\subsubsection{The existing problems in Shandong province highway network system}

(1) The network structure is not reasonable. Taking Zibo as an example, the road network structure of Southeast of Zibo region is not perfect, the road service level is affected by the roadway depth is not enough. (2) The standard of highway technical should be further improved. the city's three or four highway in total of $65 \%$ mileage in Tai'an, the standard of all road network technical is lower, part of the road damaged seriously, the conditions of road is poor. (3) There is no coordination between the network and the development of society and economy. Although the road network is being upgraded to a large-scale transformation, but still can't well adapt to the rapid development of local economy.

\section{SOME SUGGESTIONS FOR PROMOTING THE SMOOTH CHARACTERISTIC OF HIGHWAY NETWORK AND COORDINATED ECONOMIC DEVELOPMENT IN SHANDONG PROVINCE}

\subsection{Development strategy to adapt to the passengers' transportation demand levels}

(1)Improve the passenger service level comprehensively to meet the multi-level needs of passengers. Based on the feasibility on the basis of transport demand, improve the transportation service level and make all levels of transportation service products in order to adapt to the requirements of each passengers.

(2) Build the sustainable development of highway passenger transportation system, which is the development demand of the society, in order to meet the requirements of transportation in the long run.

\subsection{Development strategy to adapt to the transportation demand levels}

(1) Enhance the level of service to meet the multilevel needs of . Improve the running performance of vehicles and promote the level of road network in order to adopt to personalized demands at all levels.

(2) Establish a sustainable development of the highway system, which is the development demand of the society, in order to meet requirements of transportation in the long run.

\section{CONCLUSIONS}

(1) The smooth characteristic and the meaning of service objects of highway are stated based on the development philosophy of the transportation industry of "easy traveling of people and smooth flow of goods".

(2) The technical and economic evaluation system of highway network smooth characteristic is established based on the transportation demands of service objects - passengers and goods owners in Shandong province.

(3) Some beneficial suggestions for promoting the smooth characteristic of highway network and coordinated economic development in Shandong province are put forward based on the existing problems. Research results can meet the requirements of transportation in the long run.

\section{ACKNOWLEDGMENT}

This work was financially supported by the The Central University Special Fund for Basic Scientific Research (2013G6231001).

\section{REFERENCES}

[1] Qin, H. R. 2005. The configuration research of highway service area based on the demand analysis of service object. Xi 'an: Chang 'an University.

[2] Amy, H. 1998. Changing intra-metropolitan accessibility in the USA: evident from Atlanta. Transportation Research Part B, 49 (2): 55-107.

[3] Wu, Q. Q. \& Yang, X. \& Wang, Z. 2007. The quality analysis and demand forecast of road transport supply and demand. Journal of Chang 'an University (JCR Social Science Edition), 2007 (12): 6-19.

[4] Zhang, S. R. 2002. Highway Traffic Analysis and Evaluation of Sustainable Development. Xi 'an: Chang 'an University. 